\title{
Systematic Review of Studies on Telomere Lengths in Patients with Multiple Sclerosis
}

$8{ }^{1}$ Rostock University Medical Center, Department of Neurology, Division of Neuroimmunology, 
medRxiv preprint doi: https://doi.org/10.1101/2020.11.23.20236992; this version posted November 24, 2020. The copyright holder for this preprint (which was not certified by peer review) is the author/funder, who has granted medRxiv a license to display the preprint in It is made available under a CC-BY-ND 4.0 International license .

\section{Highlights}

17 - The relationship between aging and the pathophysiology and course of MS is not fully understood

18 - We have identified seven studies that analyzed telomere lengths ( $T L$ ) in patients with MS

19 - Our meta-analysis revealed significantly shorter leukocyte TL in MS patients compared to healthy controls

20 - There is evidence that individual variability in biological aging reflects clinical heterogeneity in MS

21 - The potential use of TL as a biomarker of age-related disease mechanisms deserves further investigation 
medRxiv preprint doi: https://doi.org/10.1101/2020.11.23.20236992; this version posted November 24,2020 . The copyright holder for this preprint (which was not certified by peer review) is the author/funder, who has granted medRxiv a license to display the preprint in It is made available under a CC-BY-ND 4.0 International license .

\section{Abstract}

23 BACKGROUND: Telomeres are protective cap structures at the end of chromosomes that are 24 essential for maintening genomic stability. Accelerated telomere shortening is related to 25 premature cellular senescence. Shortened telomere lengths (TL) have been implicated in the pathogenesis of various chronic immune-mediated and neurological diseases.

OBJECTIVE: We aimed to systematically review the current literature on the association of TL as a measure of biological age and multiple sclerosis (MS).

METHODS: A comprehensive literature search was conducted to identify original studies that presented data on TL in samples from MS patients. Quantitative and qualitative information was extracted from the articles to summarize and compare the studies.

RESULTS: A total of 51 articles were screened, and 7 of them were included in this review. In 6 studies, average TL were analyzed in peripheral blood cells, whereas in one study, bone marrow-derived cells were used. Four of the studies reported significantly shorter leukocyte TL in at least one MS subtype in comparison to healthy controls ( $p=0.003$ in meta-analysis). Shorter telomeres in MS patients were found to be associated, independently of age, with greater disability, lower brain volume, increased relapse rate and more rapid conversion from relapsing to progressive MS. However, it remains unclear how telomere attrition in MS may be linked to oxidative stress, inflammation and age-related disease processes.

CONCLUSIONS: Despite few studies in this field, there is substantial evidence on the association of TL and MS. Variability in TL appears to reflect heterogeneity in clinical presentation and course. Further investigations in large and well-characterized cohorts are warranted. More detailed studies on TL of individual chromosomes in specific cell types may

Keywords: multiple sclerosis, telomeres, telomere length measurement, biological aging, 
medRxiv preprint doi: https://doi.org/10.1101/2020.11.23.20236992; this version posted November 24,2020 . The copyright holder for this preprint (which was not certified by peer review) is the author/funder, who has granted medRxiv a license to display the preprint in It is made available under a CC-BY-ND 4.0 International license .

\section{Introduction}

Multiple sclerosis (MS) is an autoimmune disease, which affects the central nervous system (CNS). The disease usually begins in early adulthood [1], and approximately 2.8 million people live with MS worldwide [2]. MS is characterized by chronic inflammation, demyelination, gliosis and progressive axonal loss [3]. A hallmark of MS is the formation of focal lesions in the brain and spinal cord, which is mediated by the infiltration of immune cells [3]. The lesion sites are highly variable and thus every neurological symptom is possible. In consequence, the clinical presentation of individual MS patients is very heterogeneous, and symptoms can range from slight to very severe. Common initial symptoms of MS are optic neuritis, fatigue and paresthesia. The severity of MS is usually rated by the Expanded Disability Status Scale (EDSS), which considers cognitive and functional disabilities of MS patients and ranges from 0 (no abnormalities) to 10 (death as a result of MS) [4].

Most patients (85\%) present with relapsing-remitting multiple sclerosis (RRMS), while $15 \%$ are diagnosed with primary progressive multiple sclerosis (PPMS) at disease onset [1,5]. RRMS is characterized by episodes of new or worsened preexisting symptoms (relapses), followed by periods of clinical stability (remission). In nearly $60 \%$ of RRMS cases, the disease turns after an average disease duration of 20 years into a secondary progressive course of MS (SPMS) [5]. Although patients with progressive MS typically do not experience relapses, they get steadily worse due to ongoing neurodegeneration, and superimposed attacks are possible [6].

The susceptibility to develop MS is up to three times higher for women compared to men $[7,8]$, and female patients have an approximately $20 \%$ higher relapse rate [9]. Besides sex, former viral infections with Epstein-Barr virus $[10,11]$ or human herpes virus $6 A$ [12], vitamin D deficiency $[10,13]$ and certain lifestyle factors, such as adolescent obesity and smoking [14], are established risk factors for MS $[13,14]$. Moreover, the individual risk of MS is determined by genetic predisposition, especially by genes of the major histocompatibility complex (MHC) [15]. Among the most prominent ones, HLA class II allele HLA-DRB1*15:01 increases the risk of MS [15-17], whereas class I HLA-A*02:01 has a protective effect [17]. Furthermore, about 200 nonMHC loci were found to be associated with MS susceptibility by international genome-wide association studies $[18,19]$. 
medRxiv preprint doi: https://doi.org/10.1101/2020.11.23.20236992; this version posted November 24,2020 . The copyright holder for this preprint (which was not certified by peer review) is the author/funder, who has granted medRxiv a license to display the preprint in It is made available under a CC-BY-ND 4.0 International license.

Within the last years, telomeres were shown to contribute to the pathomechanisms of various complex diseases $[20,21]$. Telomeres are nucleoprotein structures found at the end of each chromosome arm. In humans, they are composed of 5 - 15 kilobases $(\mathrm{kb})$ long tandem repeats of the hexanucleotide TTAGGG $[22,23]$ and six-subunit protein complexes, called shelterin $[22,24]$. The main roles of telomeres are the maintenance and protection of genetic information as well as the regulation of cellular replication capacity [24,25].

Telomere length (TL) shortens with age as a physiological process and subject to genetic and lifestyle factors (Figure 1). The length of telomeres decreases continuously because of the endreplication problem [22]. This refers to the issue that during every DNA replication cycle, the end of the lagging strand cannot be fully replicated. As a result, there is a loss of genomic sequence with every cell division. Accordingly, human telomeres shorten by approximately 50 to 70 base pairs per year [26]. In consequence, there is an upper limit in the number of cell divisions for a normal cell population, which is called the Hayflick limit [27]. Apart from aging, every process that provokes an accelerated shortening of TL can promote cellular senescence or apoptosis. In particular, telomeres are vulnerable to oxidative stress, which can be enhanced by smoking and dietary habits [22,28]. Moreover, chronic inflammation [29] and persistent viral infections $[30,31]$ are well known to be associated with increased telomere attrition. In addition, lower physical activity was found to be linked with shorter telomeres [32].

Elongation and maintenance of telomeres is mainly controlled by a ribonucleoprotein complex called telomerase. It consists of the catalytic subunit telomerase reverse transcriptase (TERT) and the telomerase RNA component (TERC), which serves as a template for the addition of telomeric repeats. High telomerase levels are a hallmark of germline progenitor cells as well as embryonic stem cells, whereas most human cells display low or absent telomerase activity [33]. On the other hand, telomerase reactivation has been detected in $90 \%$ of all malignant tumors $[34,35]$. The transcription of TERT is regulated by many factors, including telomere length, hormones and viruses [22].

Diverse methods for the measurement of TL have been developed within the last 20 years. The traditional method is to assess the mean telomere restriction fragment (TRF) length of whole genomic DNA by Southern blot [36]. In 2002, Cawthon invented a real-time quantitative 
medRxiv preprint doi: https://doi.org/10.1101/2020.11.23.20236992; this version posted November 24,2020 . The copyright holder for this preprint (which was not certified by peer review) is the author/funder, who has granted medRxiv a license to display the preprint in It is made available under a CC-BY-ND 4.0 International license .

106

107

polymerase chain reaction (qPCR) assay [37]. In this method, a ratio of telomere signals ( $T$ ) and single-copy gene signals $(\mathrm{S})$, which are obtained in separate reaction wells, is calculated to determine relative T/S ratios that are proportional to the average TL of a biological sample [37]. Samples with a T/S > 1.0 have an average TL greater than that of the reference used. Cawthon later described an adapted monochrome multiplex qPCR (mmqPCR) assay, where the same well is used for amplification of both telomeric and single-copy DNA regions [38]. To measure telomeres of individual chromosomes, there are techniques such as quantitative fluorescence in situ hybridization (Q-FISH), universal single telomere length analysis (U-STELA) and telomere shortest length assay (TeSLA) for quantitation of the shortest telomeres [39], but each method has some limitations, as reviewed elsewhere $[36,40]$.

Studies exploring TL as disease-associated biomarker typically use peripheral blood samples as source of DNA. Only few studies so far have investigated TL distributions in specific human cell subtypes and in non-blood disease-relevant tissues. However, recent reports suggest that whole blood TL is suited as a proxy for TL in many tissue types [41], even though the decline in TL with age varies between leukocyte subpopulations [42]. In comparison with healthy controls, shorter TL in leukocytes have been associated with several diseases including cardiovascular disease, type 2 diabetes, Alzheimer's disease (AD) and autoimmune diseases, such as rheumatoid arthritis $[20,21]$. On the other hand, relatively long TL have been implicated in some types of cancer [43]. Since MS is a chronic inflammatory and neurodegenerative disease, telomeres may be linked to the development and course of this disease as well.

Here, we provide a comprehensive systematic review and meta-analysis of studies that analyzed TL in patients with MS. The studies were evaluated with regard to the respective study design and the employed TL measurement approach. We summarize the available evidence on the association of TL with MS subtypes. Moreover, we discuss how shorter TL may be involved in the molecular mechanisms underlying MS and whether telomeres as marker of cellular senescence may be suitable for predicting disease progression. 
medRxiv preprint doi: https://doi.org/10.1101/2020.11.23.20236992; this version posted November 24,2020 . The copyright holder for this preprint (which was not certified by peer review) is the author/funder, who has granted medRxiv a license to display the preprint in It is made available under a CC-BY-ND 4.0 International license .

\section{2. Methods}

\section{2.1. Search strategy and study selection criteria}

134 For this review, we systematically searched for published articles on TL in MS patients. This 135 was done by taking into account the Preferred Reporting Items for Systematic Reviews and 136 Meta-Analyses (PRISMA) and by following the steps "identification", "screening", "eligibility" and "inclusion" [44]. Accordingly, we considered the current PRISMA recommendations and checklist in the design and conduct of this review.

The literature search was executed using the PubMed database as well as the preprint repositories bioRxiv and medRxiv to capture the latest research articles available. For identification of relevant papers, we wanted the search to be sensitive and potentially overinclusive so that no relevant articles are missed. Therefore, only two terms, "multiple sclerosis" and "telomer", combined using the Boolean operator AND, were entered in the respective search interfaces. The asterisk wildcard symbol (*) was used for search term truncation. The latest check of this search was on November $19^{\text {th }}, 2020$. The reference lists of all included articles were also scanned with the aim to identify further studies on the same topic. The literature search was not limited by date of publication. reviewers (JB and $\mathrm{MH}$ ). The criteria for study selection were defined previously. We included studies that were written in English or German (I) and that appeared either in a scholarly journal or in an open access preprint repository. Moreover, we excluded papers that were no original research articles (II) and studies that did not include MS patients (III). Finally, we rejected studies that did not present data on TL (IV). Studies not meeting the inclusion criteria were excluded, and the reasons for exclusion were recorded. During the eligibility step, there was no restriction with regard to the course of MS, disease duration, disease severity, MS treatment, cohort size, race/ethnicity of patients and controls, type of sample material or TL measurement method used. 
medRxiv preprint doi: https://doi.org/10.1101/2020.11.23.20236992; this version posted November 24,2020 . The copyright holder for this preprint (which was not certified by peer review) is the author/funder, who has granted medRxiv a license to display the preprint in It is made available under a CC-BY-ND 4.0 International license .

\subsection{Data extraction}

For comparing the remaining studies, relevant data was obtained from tables, graphs and statistical analyses described in the text. Data extraction was carried out using a predesigned data sheet by one reviewer (JB) and verified by another $(\mathrm{MH})$. Any discrepancies were resolved by discussion. Accordingly, we created a table, which contained the main information for each study. More specifically, we collected information about the study design, the country of origin, the collection of biological samples (e.g., cross-sectional vs. longitudinal), the kind of cells that were used (e.g., peripheral blood leukocytes), the method utilized to determine TL (e.g., qPCR assay or TRF analysis) as well as clinical-demographic data about the patient cohort (e.g., the distribution of age and sex, the patients' clinical course of MS [6] and the diagnostic criteria that were applied [45-47]). Additionally, we identified group comparisons (e.g., MS patients vs. controls, RRMS vs. PPMS, women vs. men) and strategies to control for confounding (e.g., matching or statistical regression) and recorded whether or not the findings reported in the respective studies reached statistical significance.

We have primarily conducted a narrative summary of the results, because the designs and methods of the included studies were quite different. Nonetheless, to further examine the relationship between TL and MS, a meta-analysis was performed as well. We used the metafor $\mathrm{R}$ package [48] for this analysis and for preparing a forest plot and a funnel plot. Means and standard deviations of TL that were reported in the studies for MS patients and controls were used to calculate standardized mean differences (SMD, also known as Cohen's d) and 95\% confidence intervals. A random-effects model was then fitted to the data to estimate the composite effect size. Heterogeneity across studies was evaluated by calculating the Q statistic $p$-value. Egger's regression test was used to detect potential publication bias [49]. Due to the lack of data, we decided against additional subgroup analyses. 
medRxiv preprint doi: https://doi.org/10.1101/2020.11.23.20236992; this version posted November 24,2020 . The copyright holder for this preprint (which was not certified by peer review) is the author/funder, who has granted medRxiv a license to display the preprint in It is made available under a CC-BY-ND 4.0 International license .

\section{Results}

183

184

185

\subsection{Search results, study selection and overview}

We ended up with 49 publications from our literature search in the PubMed database. Another 2 articles were found in bioRxiv and medRiv. No additional articles were found to be relevant by reference list screening. All articles were in English language (I). The full-texts of all articles were assessed for eligibility in accordance with the PRISMA statement guidelines [44]. The study selection process excluded most of the listed records as presented in the flow diagram (Figure 2): Five articles were excluded because they did not present original research (II). Subsequently, 18 studies were discarded because they did not contain an analysis of MS patient samples (III), and finally, 21 studies were rejected because they were not concerned with measuring TL (IV). In consequence, we included 7 studies in our systematic review [50-56] (Supplemental Table 1). Four of these studies also provided sufficient data to be pooled into a meta-analysis $[51,52,55,56]$. We then gathered diverse information from the selected articles, e.g., study design, sample size, patient characteristics, TL measurement method and cell population under scrutiny.

The seven included studies were published within the last five years, except the study by Hug et al., which was already published in 2003 [50]. The studies were conducted by six different research groups with either Asian $(n=2)$, European $(n=4)$ or American $(n=1)$ MS patient cohorts. In all studies, the collection of patient samples was performed in a cross-sectional manner, while three studies additionally used longitudinal blood sample series obtained over a period of up to $>10$ years $[52,54,56]$. With one exception [54], all studies compared TL between MS patients and controls. The number of patients included in the investigation of telomeres ranged from 10 [53] to 516 [54]. In the following section, we have summarized the objectives and findings for each of the individual studies.

\subsection{Characteristics and results of the included studies}

The first study was published by Hug et al. [50]. They explored whether there are TL differences in T cells between RRMS patients $(n=20)$ and age-matched healthy controls $(n=20)$. 
medRxiv preprint doi: https://doi.org/10.1101/2020.11.23.20236992; this version posted November 24,2020 . The copyright holder for this preprint (which was not certified by peer review) is the author/funder, who has granted medRxiv a license to display the preprint in It is made available under a CC-BY-ND 4.0 International license .

209 For this purpose, mean TRF lengths were determined for CD4+ and CD8+ cells that were 210 isolated by magnetic separation (positive selection) from peripheral blood mononuclear cells. 211 The research group observed a decline of TL with age in MS patients as well as in controls in 212 both cell populations. However, they did not find any statistically significant difference in relative 213 TL or age-dependent telomere shortening between the patients and controls. The TL were also 214 similar in the two T cell subsets: The CD4+ and CD8+ T cells had a mean TL of $10.1 \mathrm{~kb}$ and $2159.2 \mathrm{~kb}$ in patients with MS and $8.8 \mathrm{~kb}$ and $9.4 \mathrm{~kb}$ in controls, respectively. Hug et al. also 216 investigated the enzymatic activity of telomerase in the circulating T cells. Telomerase activity 217 was detectable at low levels and was slightly higher in CD4+ cells compared with CD8+ cells, 218 but there was no significant difference between the MS patient group and the healthy control 219 group. The authors concluded that there is no evidence of an accelerated T cell turnover, but 220 that an altered T cell composition in MS may interfere with peripheral immune tolerance 221 mechanisms.

222 The study by Guan et al. from 2015 [51] enrolled 59 patients with MS (benign RRMS: $\mathrm{n}=19$, 223 SPMS: $n=20$, PPMS: $n=20$ ) and 60 healthy individuals. The MS and control groups were similar 224 with regard to age and sex distribution as well as lifestyle and dietary habits. Subjects with 225 infections, diabetes, habitual smoking status or corticosteroid use within the past 3 months 226 were excluded. The average TL in peripheral blood cells was then assessed by TRF analysis. 227 The authors found significantly shorter TL, on average, in PPMS patients (6.5 kb in men and $2287.0 \mathrm{~kb}$ in women) compared to controls (8.4 kb in men and $10.1 \mathrm{~kb}$ in women), whereas the TL 229 in RRMS and SPMS patients did not differ significantly from those in controls. Guan et al. also 230 reported a clear negative association of TL and age for the control group, regardless of sex, 231 and for male SPMS patients. Moreover, they evaluated markers of oxidative stress in plasma 232 and urine. This revealed significantly elevated levels of urinary 8-iso-PGF2 $\alpha$ (a marker of lipid 233 peroxidation) and reduced antioxidant capacity of plasma lipoproteins in MS, especially in 234 PPMS. However, there was no significant relationship between TRF results and oxidative 235 stress markers in either group of subjects. In sum, these data suggested that enhanced 236 oxidative damage and shorter somatic TL distinguish in particular MS patients with a primary 237 progressive course of disease. 
medRxiv preprint doi: https://doi.org/10.1101/2020.11.23.20236992; this version posted November 24,2020 . The copyright holder for this preprint (which was not certified by peer review) is the author/funder, who has granted medRxiv a license to display the preprint in It is made available under a CC-BY-ND 4.0 International license .

The subsequent study by Guan et al. from 2018 [52] analyzed TL and systemic peroxidation in 34 MS patients and 44 healthy subjects. The two cohorts had a similar female:male ratio and average age, and the exclusion criteria were as in the former study [51]. However, in this study, MS patient samples were collected at two time points to evaluate the biological and clinical effects of antioxidant vitamin E supplementation. Accordingly, half of the patients received a-tocopherol (400 mg/day) for 3 months and the other half (matched for age and sex) did not. TL were measured by TRF analysis using genomic DNA from peripheral blood (i.e., circulating leukocytes). Additionally, Guan et al. employed serum samples for testing oxidation of lowdensity lipoproteins (LDL) and urine samples for determining 8-iso-PGF2 $\alpha$ concentrations. As a result, in line with their previous study, significantly shorter average TL were observed in MS patients $(6.9 \pm 1.0 \mathrm{~kb})$ compared to controls $(9.1 \pm 1.4 \mathrm{~kb})$. The MS group was also characterized by significantly higher levels of urinary 8-iso-PGF2 $\alpha$ and lower antioxidant capacity in serum. Following vitamin E administration, 8-iso-PGF2 $\alpha$ levels were significantly reduced by nearly $20 \%$. However, the treatment over 3 months appeared not to be long enough to detect significant changes in TL or clinical parameters (e.g., EDSS scores). This study thus confirmed shorter TL in MS patients and indicated that antioxidants, such as vitamin E, may be useful to attenuate enhanced oxidation conditions present in MS.

Redondo et al. [53] used bone marrow-derived mesenchymal stromal cells (MSC) from 10 patients with progressive MS and 6 controls with osteoarthritis. These multipotent MSCs were expanded in vitro and harvested at passage number P2 and P6 to measure TL by TRF analysis. The authors found no significant difference in TL between samples derived from controls and MS patients. Duration of disease progression and subtype of progressive MS were also not associated with TL. However, significant effects of age $(p=0.024)$ and passage number $(p<0.0001)$ were detected by multivariable regression: TL correlated negatively with age and decreased from P2 to P6 in both control and MS MSCs. This decrease only reached statistical significance in MS MSCs. Moreover, these cells were characterized by reduced in vitro expansion potential. Redondo et al. thus concluded that telomere shortening is accelerated in MSCs from MS patients, suggesting that premature cellular aging and senescence may contribute to the pathophysiology of MS. 
medRxiv preprint doi: https://doi.org/10.1101/2020.11.23.20236992; this version posted November 24,2020 . The copyright holder for this preprint (which was not certified by peer review) is the author/funder, who has granted medRxiv a license to display the preprint in It is made available under a CC-BY-ND 4.0 International license .

Krysko et al. [54] performed the so far largest and most elaborated study on TL in MS. They used whole blood DNA samples of 516 patients, including 80 individuals with clinically isolated syndrome (CIS) and 367 RRMS patients. These patients were studied for up to 10 years from baseline by clinical assessments and magnetic resonance imaging (MRI). For a subset of 46 individuals, DNA samples from multiple time points were analyzed. This subset consisted of a group of patients who converted to SPMS $(n=23)$ and a group of patients who remained in the RRMS stage $(n=23)$, while matching for potential confounders such as age and sex. The average leukocyte telomere lengths (LTL) were then measured by real-time qPCR [37], and the resulting T/S ratios were scaled by -0.2 to ease the interpretation of regression coefficients.

The cross-sectional analyses over the entire patient cohort revealed that higher age and disease duration were clearly associated with shorter LTL $(p<0.001)$, while there was no significant association between LTL and sex, body mass index (BMI), smoking status or type of MS treatment. More importantly, shorter telomeres were associated with greater disability and brain atrophy, after adjusting for age, sex and disease duration: For every 0.2 unit lower LTL, the baseline EDSS score was 0.27 units higher $(p<0.001)$ and total brain volume and white matter volume were $7.4 \mathrm{~mm}^{3}$ and $4.0 \mathrm{~mm}^{3}$ lower, respectively $(p<0.05)$. The effect of age on EDSS that is mediated by LTL was estimated to be $15.1 \%$ by mediation analysis. The authors also assessed the association of baseline LTL with change in clinical and MRI outcomes over time. Based on adjusted models, they found LTL to be weakly associated with the rate of change in $\operatorname{EDSS}(p=0.06)$ and cortical gray matter volume decline $(p=0.02)$. Moreover, among the patients with RRMS, for every 0.2 unit decrease in LTL, a 1.27 times higher relapse rate was noted $(p=0.001)$. In the subset of 46 patients with LTL measured longitudinally over up to 10 years of follow-up, a -0.2 unit change in LTL was associated with an EDSS score increase by $0.34(p=0.012)$. In this subset, patients also had 1.4 times the odds of converting from RRMS to SPMS for every 0.2 unit lower baseline LTL, although this finding did not reach statistical significance $(p=0.40)$. However, it has not been reported whether there were also differences in average LTL between patients with different subtypes of MS in the full cohort. In sum, this study convincingly showed that TL is associated with disability progression independent of age and disease duration, suggesting that individual variability in biological aging may contribute to clinical heterogeneity in MS. 
medRxiv preprint doi: https://doi.org/10.1101/2020.11.23.20236992; this version posted November 24,2020 . The copyright holder for this preprint (which was not certified by peer review) is the author/funder, who has granted medRxiv a license to display the preprint in It is made available under a CC-BY-ND 4.0 International license .

Habib et al. [55] assessed TL in whole blood DNA samples of 138 MS patients and 120 healthy controls. Three MS groups were distinguished: RRMS ( $n=102)$, SPMS $(n=27)$ and PPMS $(n=5)$, while 4 patients had an undefined course of MS. The RRMS patients were the youngest (average age: 35.2 years), followed by healthy controls (44.6 years), PPMS patients (49.0 years) and SPMS patients (51.8 years) $(p<0.001)$. The groups were also not matched by sex (MS: $37.7 \%$ male, controls: $54.2 \%$ male). Relative LTL were determined using the mmqPCR method by Cawthon [38]. Significantly shorter LTL were observed in all 3 groups of MS patients (mean T/S: RRMS: $0.76 \pm 0.22$; SPMS $0.67 \pm 0.21$; PPMS $0.67 \pm 0.27$ ) as compared with the controls $(0.94 \pm 0.25)(p<0.001$ with adjustment for age as covariate). No significant difference in TL was observed between men and women, but a strong negative relationship between age and TL was seen in both controls and MS patients $(p<0.001)$. Accordingly, the patients with a progressive course of disease (PPMS and SPMS), which were much older, had shorter telomeres than the patients with RRMS. Shorter TL also correlated with higher EDSS scores $(p=0.001)$, but this association was again driven by age. Additionally, Habib et al. conducted an in vitro experiment using lymphoblastoid cell lines ( $L C L)$ generated from peripheral blood B cells. This analysis revealed shorter TL in LCL from MS patients $(n=3)$ compared to controls $(n=3)$ but overall similar dynamics of telomere loss over up to 15 passages of cultivation in both groups. The authors therefore speculated whether accelerated telomere shortening may precede MS onset.

The most recent study by Hecker et al. [56] comprised 40 RRMS patients, 20 PPMS patients and 60 healthy controls. Those three groups were well matched for age (with an average of 48.0 years and 48.1 years for patients and controls, respectively) and sex (female:male ratio always 1:1). The average LTL was determined for all subjects by multiplex qPCR [38] using DNA from peripheral whole blood samples. The data were analyzed in relation to the long-term clinical course of the patients. To this end, relapses and progression of disability were evaluated over a period of up to 10 years after the blood sampling. For a subset of $10 \mathrm{MS}$ patients, a second blood sample was collected after this follow-up period. In the longitudinal analysis, LTL decrease over time was seen for all patients $(p<0.001)$, independent of disease subtype. In the cross-sectional analysis, significantly shorter telomeres could be detected in the 
medRxiv preprint doi: https://doi.org/10.1101/2020.11.23.20236992; this version posted November 24,2020 . The copyright holder for this preprint (which was not certified by peer review) is the author/funder, who has granted medRxiv a license to display the preprint in It is made available under a CC-BY-ND 4.0 International license .

group of RRMS patients (mean T/S = 0.92) compared to the PPMS patients (mean T/S = 1.16) and controls (mean T/S = 1.12) $(p=0.003)$. No significant differences were found between the PPMS group and controls as well as between women and men. However, age was negatively associated with LTL in all 3 study cohorts. Hecker et al. divided the subjects into two groups with relatively short $(T / S$ ratio $<1$ ) or long telomeres $(T / S$ ratio $>1)$. Patients with RRMS were less likely to belong to the long telomere group (odds ratio $=0.399, p=0.032$ ), and those with relatively short LTL were also at much higher risk to convert to SPMS in the 10-year follow-up (hazard ratio $=8.308, p=0.050$ ) in age-adjusted tests. On the other hand, the LTL of RRMS patients at baseline had little value in terms of predicting the rate of change in EDSS and the risk of subsequent relapses. Nevertheless, these data suggest that LTL as a biomarker for immunosenescence may capture age-related disease mechanisms.

The following section presents an integrative comparison of study methods and results that were presented in the papers included in this review.

340 Five of the identified studies included a healthy control group (Table 1), while Redondo et al. [53] used samples of patients with osteoarthritis as controls. The study by Krysko et al. [54] is the only one that did not include a control group. However, their study comprised the largest number of MS patients $(n=516)$ with the aim to detect associations of LTL with changes in clinical and MRI metrics over a follow-up period of 10 years. Differences between the studies were also noted with regard to the MS population under scrutiny (Table 1): In the majority of studies, the diagnosis of MS was confirmed using the original or revised McDonald criteria from 2001/2005 [46,47]. The early study by Hug et al. [50] was based on patients diagnosed with relapsing MS according to the Poser criteria from 1983 [45], whereas Redondo et al. [53] did not specify the applied diagnostic criteria and considered only cases with progressive MS. Differences in LTL between subgroups of MS patients with different courses of disease (RRMS, SPMS and PPMS) were examined in 3 of the 7 studies $[51,55,56]$. Patients with CIS were included only in the analysis by Krysko et al. [54]. The second study by Guan et al. [52] is 
medRxiv preprint doi: https://doi.org/10.1101/2020.11.23.20236992; this version posted November 24,2020 . The copyright holder for this preprint (which was not certified by peer review) is the author/funder, who has granted medRxiv a license to display the preprint in It is made available under a CC-BY-ND 4.0 International license .

currently the only one that investigated the effects of a therapeutic intervention (vitamin $\mathrm{E}$ administration) on TL in blood cells of MS patients.

More men than women were included in the studies by Redondo et al. [53] and Guan et al. [51,52], whereas the proportion of female MS patients was $68.6 \%$ in the study by Krysko et al. [54]. There were also huge differences between the studies with regard to the age of the patients: For instance, the patients in the studies by Guan et al. had an average age of 32.8 years [52] and 33.3 years [51], respectively, whereas the TL analysis by Redondo et al. was conducted in a much older group of MS patients, with a mean age of 54.1 years [53]. Notably, the latter two research groups as well as Hecker et al. [56] paid specific attention to ensure that the cohorts to be compared were well matched in terms of age and sex. There was no control group in the study of Krysko et al., but in the subset of patients that had LTL measured over time for comparing SPMS converters $(n=23)$ and non-converters $(n=23)$, a careful matching for age, sex, disease duration and EDSS score was carried out [54]. On the other hand, the cohorts in the study by Habib et al. had uneven age and sex distributions [55], and Hug et al. only reported that the MS patients and healthy controls were age-matched [50].

In 5 out of the 7 reviewed studies, whole blood samples were used for TL analysis (Table 2). In these studies, leukocytes are the main source of telomeric DNA as human erythrocytes and platelets have no cell nucleus. The measurement of leukocyte TL provides a rough insight into the average length of telomeric ends in a heterogeneous population of granulocytes, lymphocytes and monocytes. So far, only the study by Hug et al. [50] used specific immune cells, namely peripheral blood CD4+ and CD8+ T cells, for assessing TL in MS patients. As an exception, Redondo et al. [53] made use of MSCs that were isolated from bone marrow samples, as they were interested in exploring the bone marrow microenvironment in the context of autologous MSC-based therapy for progressive MS. In their study as well as in the study by Habib et al. [55], experiments with patient-derived cells maintained in culture were performed to examine the dynamics of telomere attrition in vitro. telomeres per cell has been evaluated. So far, no study investigated TL heterogeneity in single cells and telomeres of single chromosome arms in MS patient samples. In 4 of the 7 studies 
medRxiv preprint doi: https://doi.org/10.1101/2020.11.23.20236992; this version posted November 24,2020 . The copyright holder for this preprint (which was not certified by peer review) is the author/funder, who has granted medRxiv a license to display the preprint in It is made available under a CC-BY-ND 4.0 International license .

[50-53], TL were determined by non-radioactive TRF analysis, with only minor differences in the applied protocol: Following electrophoretic separation of digested DNA and Southern blotting, DNA fragments were hybridized to digoxigenin-labeled telomere-specific probes, incubated with anti-digoxigenin antibodies conjugated to alkaline phosphatase, and detected on the blot using chemiluminescent enzyme substrates. In the other 3 studies, qPCR assays were employed: Krysko et al. [54] used the qPCR method by Cawthon from 2002 [37], while Habib et al. [55] and Hecker et al. [56] used the adapted mmqPCR assay by Cawthon from 2009 [38]. In both qPCR-based approaches, relative TL are measured as T/S ratios.

In the studies that have been published so far, no significant TL differences between women and men were described. However, with one exception, all studies reported a clear negative association of chronological age and TL as a marker of biological age, as expected. To consider such data dependencies in the groups to be compared, control for confounding was implemented at the level of the statistical analysis in 5 of the 7 studies (Table 2): Habib et al. [55] and Hecker et al. [56] employed age- and sex-adjusted linear models to assess differences in LTL between patients and controls or associations to clinico-demographic parameters. Redondo et al. considered the independent effects of participant age and passage number in the comparative analysis of TL in cultured MSCs from MS patients and controls [53]. Hug et al. included age as covariate affecting TL in CD4+ and CD8+ T cells [50]. Finally, Krysko et al. used regression models adjusted for age, sex and disease duration [54]. They also evaluated smoking, BMI, type of MS treatment and HLA-DRB1*15:01 carrier status as potential confounders. However, as these variables were not associated with LTL in the study cohort, they were not retained in the final models. On the other hand, one should be aware that the possibility of residual or unmeasured confounding cannot be excluded in general.

Collectively, the present studies provide compelling evidence that the telomeres of immune cells in the peripheral blood are typically shorter in patients with MS. Significantly shorter LTL in at least one MS subtype were consistently found in 4 of the studies (Table 2). In the studies by Guan et al., the measured TL were on average $26 \%$ and $24 \%$ shorter in the PPMS subgroup [51] and in the general MS group [52], respectively, as compared to the controls. In line with this, Habib et al. found significantly shorter telomeres in each MS subgroup (RRMS: 19\%, 
medRxiv preprint doi: https://doi.org/10.1101/2020.11.23.20236992; this version posted November 24,2020 . The copyright holder for this preprint (which was not certified by peer review) is the author/funder, who has granted medRxiv a license to display the preprint in It is made available under a CC-BY-ND 4.0 International license .

411 SPMS: 29\% and PPMS: 29\% shorter) [55], and, finally, Hecker et al. observed 18\% shorter LTL 412 in the RRMS patient cohort than in the control cohort [56]. A meta-analysis of these 4 studies 413 substantiated that LTL are significantly shorter in MS patients as compared to healthy controls 414 (overall SMD $=-0.66, p=0.003$ ). Egger's test revealed no funnel plot asymmetry $(p=0.771)$, 415 indicating no major publication bias (Figure 3). However, there was considerable amount of 416 heterogeneity in the study findings (Q test $p<0.001$ ), and no discernible differences could be 417 detected between subtypes of MS. The other 3 studies could not be included in the 418 meta-analysis due to insufficient data available. In the first study by Hug et al., no apparent 419 differences in T cell TL were reported between cases and controls [50]. Redondo et al. did also 420 not find significant TL differences, but they recognized an accelerated telomere shortening in $421 \quad$ MSCs from patients with progressive MS in vitro [53]. The remaining study by Krysko et al. did 422 not include a control group [54].

423 The more recent studies in the field also suggest that LTL as a biomarker reflects clinical 424 heterogeneity and that it may be useful to predict disease progression. Krysko et al. [54] found 425 that shorter telomeres are associated with longer disease duration, lower brain volume 426 measures in MRI and higher degrees of disability as measured by the EDSS [4]. A mediation 427 analysis indicated that LTL accounted for $15.1 \%$ of the effect of chronological age on disability 428 in their data [54]. The negative relationship between EDSS and TL was also seen by Habib 429 et al., although statistical significance was not achieved when the analysis was adjusted for age 430 [55]. In the longitudinal analyses by Krysko et al., baseline LTL was also weakly associated with 431 EDSS score worsening and cortical gray matter volume decline over time. Moreover, in the 432 subgroup of RRMS patients, a lower LTL was associated with a significantly higher relapse rate 433 in the follow-up [54]. In similar analyses by Hecker et al., RRMS patients with relatively low 434 baseline LTL had nominally higher EDSS scores over 10 years and a significantly higher 435 probability of transitioning to SPMS [56]. Therefore, despite differences in the findings by the 436 different research groups, MS patients with longer telomeres tend to have a more favorable $437 \quad$ course of the disease. 
medRxiv preprint doi: https://doi.org/10.1101/2020.11.23.20236992; this version posted November 24,2020 . The copyright holder for this preprint (which was not certified by peer review) is the author/funder, who has granted medRxiv a license to display the preprint in It is made available under a CC-BY-ND 4.0 International license .

\section{4. Discussion}

439 This is the first systematic review on studies that investigated TL in patients with MS. The 440 analysis of TL provides insights into the proliferation history of cells, as telomeres usually 441 shorten with every DNA replication. TL shortening is thus related to normal aging, but it is also 442 modulated by several environmental influences. In recent years, there has been increased 443 research interest on how the course of MS might be affected by biological aging and the 444 implicated immunological changes. As highlighted in our review, the studies in the current 445 literature show that MS patients typically have shorter telomeres in blood cells as compared to 446 controls. Moreover, it has been argued that the measurement of TL may serve as a potential 447 biomarker for assessing and predicting clinical phenotypes of MS.

The evidence of an association of relatively short TL and MS is convincing despite the fact that only few studies $(n=7)$ with small sample sizes $(n \leq 138$ patients for studies comparing against controls) and heterogeneous study populations (e.g., with regard to age, sex and ancestry) have been published so far. Interindividual variation in TL is well known to be affected by demographic factors. On average, longer telomeres were found in adult women compared to men [57], and TL are longer among people of African ancestry compared to people of European ancestry [41]. The studies that were included in this review did not describe any sex-specific differences in TL. However, further studies are needed to better understand to which extent environmental and genetic factors, including sex-related differences, may influence TL as well as risk and severity of MS. It is important to note that the patient cohorts in the reviewed studies also differed in terms of clinical characteristics. For instance, different criteria for the diagnosis of MS were applied, as these were constantly refined over the past years [45-47,58]. Moreover, relapsing and progressive forms of MS were differently represented in the studies. All this may explain some inconsistencies in the findings between the research groups. Therefore, future studies on TL in MS may employ larger patient cohorts that are also more homogeneous in terms of disease activity and progression as evaluated by clinical and MRI parameters. One approach might be to incorporate the analysis of blood cell TL in the context of large-scale observational studies or MS clinical trials. 
medRxiv preprint doi: https://doi.org/10.1101/2020.11.23.20236992; this version posted November 24,2020 . The copyright holder for this preprint (which was not certified by peer review) is the author/funder, who has granted medRxiv a license to display the preprint in It is made available under a CC-BY-ND 4.0 International license .

In most of the reviewed studies, peripheral blood samples were used to measure TL in MS patients. The collection of blood samples is rather safe and convenient, and it is also suitable for repeated assessments in longitudinal studies. However, blood is a heterogeneous composition of various cell types, which may provoke confounding effects in the analysis of TL. Studies have shown that TL and the rate of telomere shortening differ between immune cell types $[42,59,60]$. For instance, the decline in TL with age in lymphocytes is more pronounced than in granulocytes [42]. As the only research group, Hug et al. used distinct circulating cell types, namely CD4+ and CD8+ T cells, to compare TL between MS patients and healthy controls [50]. Further cell type-specific studies on TL in MS are needed. So far, there is also no TL study that used brain tissues or cerebrospinal fluid cells from MS patients. Hence, the role of CNS cell telomeres in the pathobiology of MS remains to be explored. Telomeres of non-blood cell populations have already been investigated in the context of other diseases. For example, significant differences in TL were found in buccal cells and hippocampal brain tissue from patients with $A D$ in comparison to controls [61]. TL is generally positively correlated across human tissue types, but different tissues have different cellular turnover and replacement, and some tissue types have a certain level of telomerase expression in order to maintain TL in the stem cell compartments [41]. For this reason, the analysis of TL in other tissues and body fluids may give some new information on the association of TL and MS.

In 4 of the 7 included studies, the TRF technique was used, and qPCR assays were chosen in the other 3 studies. Both approaches measure the average length of all telomeres in a cell population. Other methods have been developed to provide deeper insights into the distribution of TL and to quantify TL of specific chromosomes. Therefore, in future studies, methods like Q-FISH [62], for determining the TL of each individual chromosome ( $p$ or $q$ arm) in a particular cell, or TeSLA [39], for detecting the shortest telomeres in a sample with high sensitivity, should be taken into account. The shortest telomeres, rather than the average TL, were demonstrated to be critical for genome stability and cell viability as they trigger DNA damage responses leading to replicative senescence [63]. Therefore, more advanced methods may help to delineate cause-and-effect relationships of dysfunctional telomeres in onset and progression of 
medRxiv preprint doi: https://doi.org/10.1101/2020.11.23.20236992; this version posted November 24,2020 . The copyright holder for this preprint (which was not certified by peer review) is the author/funder, who has granted medRxiv a license to display the preprint in It is made available under a CC-BY-ND 4.0 International license .

494

495

496

MS. Moreover, they allow measuring subtle changes in the abundance of the shortest telomeres over time, which may have implications for disease monitoring.

Besides TL, there are various other markers of biological aging. In 2013, Horvath developed a predictor of age that allows to estimate the DNA methylation (DNAm) age of tissues and cell types [64]. This "epigenetic clock" focuses on cytosine-5 methylations in DNA regions where a cytosine nucleotide is followed by a guanine nucleotide (CpG). DNAm age utilizes information from 353 CpG sites, of which 193 get hypermethylated and 160 get hypomethylated with increasing age [64]. Using this measure, it has been found that men have higher epigenetic aging rates than women in blood, saliva and brain tissue [65]. In 2018, Levine et al. introduced DNAm PhenoAge, an estimate of phenotypic age based on the methylation status at $513 \mathrm{CpGs}$ that strongly correlates with age but also captures variations in morbidity and mortality outcomes [66]. Theodoropoulou et al. recently compared four age acceleration measures, including the epigenetic clock by Horvath and DNAm PhenoAge, using blood samples from MS patients [67]. They showed that the different measures reflect separate pathophysiological aspects of the disease and that MS patients have significantly higher age acceleration than healthy controls when evaluating DNAm PhenoAge in whole blood. However, a single best measure of biological aging does not exist. TL measurements and the diverse proposed epigenetic clocks reflect different molecular hallmarks of aging $[68,69]$, and each may have its own strengths in the analysis of disease-specific mechanisms.

It currently remains unclear whether shortened telomeres in MS are a cause or a consequence of the pathophysiological processes. An accelerated loss of telomeres with age is known to be attributable to systemic oxidative stress and chronic inflammation, which is associated with increased cellular turnover [28,57]. Interestingly, significantly enhanced lipid peroxidation could be detected in all MS subtypes in the studies by Guan et al. [51,52]. Elevated levels of oxidative stress markers in patients with MS are presumably connected to the inflammatory disease processes. Within the CNS, this in turn may promote demyelination and axonal degeneration and render neuronal repair mechanisms less effective. On the other hand, persistent viral infections were shown to affect TL dynamics and to trigger senescence in immune cells [30]. The accumulation of senescent cells that lack proliferative capacity has adverse consequences 
medRxiv preprint doi: https://doi.org/10.1101/2020.11.23.20236992; this version posted November 24,2020 . The copyright holder for this preprint (which was not certified by peer review) is the author/funder, who has granted medRxiv a license to display the preprint in It is made available under a CC-BY-ND 4.0 International license .

as these cells occupy cellular niches and release proinflammatory cytokines [70]. Apart from

524 this, it should be noted that chromatin organization and gene regulation are also modulated by telomere shortening even long before the initiation of DNA damage signals [71]. However, additional research efforts are required to better understand the precise interplay between immune responses and aging mechanisms in MS.

Targeting aging-related mechanisms could be an integral part of future patient care. Micronutrients, such as vitamins and minerals, can modulate oxidative stress and chronic inflammation and thereby affect TL [72]. For instance, higher serum vitamin D concentrations were shown to be associated with longer LTL [73]. Several interventional studies have investigated the effects of vitamin D supplementation in people with MS, but firm conclusions on the clinical benefits cannot yet be drawn [74]. The use of vitamin E and other antioxidants in MS patients is still unclear due to a lack of sufficiently powered studies [75]. Besides, senolytic drugs have been discussed to improve chronic diseases and functional deficits by enhancing immune-mediated clearance of senescent cells $[76,77]$. Studies with mice showed that removal of senescent cells can prevent or delay tissue dysfunction [78]. Therefore, several senolytics are now tested in clinical trials for treating diverse conditions such as frailty and AD [77], and the administration of senolytics has also been suggested as a potential strategy for delaying progression of MS [79]. The therapeutic modulation of telomerase activity is another approach that is currently being pursued mainly in cancer trials [80]. In the reviewed studies, most MS patients received a basic disease-modifying treatment (DMT), which was not found to be related to TL $[54,56]$. However, several highly efficacious immune cell depletion therapies have been approved for MS in recent years [81]. Following depletion, the repopulation kinetics vary between different cell types (e.g., B cells repopulate much faster than T cells). These therapies To conclude, there is an increased number of studies on the role of telomere attrition in thus have a sustained impact on the immune system. The induced long-term immunological changes probably correlate with changes in TL of circulating lymphocytes. However, the possible relevance of TL dynamics in response to specific MS therapies has not yet been investigated. 
medRxiv preprint doi: https://doi.org/10.1101/2020.11.23.20236992; this version posted November 24, 2020. The copyright holder for this preprint (which was not certified by peer review) is the author/funder, who has granted medRxiv a license to display the preprint in It is made available under a CC-BY-ND 4.0 International license .

552 context of MS. Despite differences in study design and methodology, the findings of the studies

553 overall point to shorter telomeres in blood cells of MS patients in comparison to controls, which

554 was supported by our meta-analysis. Shorter TL were also associated with greater disability

555 and brain atrophy as well as disease progression independent of chronological age. This

556 suggests that biological aging is related to inflammation and neurodegeneration in MS and that

557 the assessment of TL as a biomarker of immunosenescence may provide useful information

558 regarding the individual course of disease. However, further research is needed to better

559 understand the complex relationship between aging and the pathobiology of MS. Subsequent

560 studies may explore the distribution of the shortest telomeres in specific immune cell subtypes

561 and brain cells. This may yield deeper insights into the pathophysiology of MS and allow to

562 develop novel therapeutic strategies targeting aging-related mechanisms. 
medRxiv preprint doi: https://doi.org/10.1101/2020.11.23.20236992; this version posted November 24,2020 . The copyright holder for this preprint (which was not certified by peer review) is the author/funder, who has granted medRxiv a license to display the preprint in It is made available under a CC-BY-ND 4.0 International license .

\section{Abbreviations}

$564 \quad A D$

$565 \quad \mathrm{BMI}$

$566 \quad$ CIS

$567 \quad$ CNS

$568 \quad$ CpG

$569 \quad$ DMT

570 DNA

571

572

573

574

575

576

577

$578 \quad \mathrm{MHC}$

579 mmqPCR

$580 \quad$ MRI

$581 \quad$ MS

$582 \quad$ MSC

$583 \quad n$

584 n.c.

585 n.i.

$586 \quad \mathrm{P}$

$587 \quad$ PCR

$588 \quad$ PPMS

589 PRISMA

590 Q-FISH

591
Alzheimer's disease

body mass index

clinically isolated syndrome

central nervous system

cytosine and guanine separated by a single phosphate group

disease-modifying treatment

deoxyribonucleic acid

DNA methylation

Expanded Disability Status Scale

human leukocyte antigen

kilobase

lymphoblastoid cell line

low-density lipoprotein

leukocyte telomere length

major histocompatibility complex

monochrome multiplex qPCR

magnetic resonance imaging

multiple sclerosis

mesenchymal stromal cell

number

no control group

no information

passage number of in vitro expansion

polymerase chain reaction

primary progressive multiple sclerosis

Preferred Reporting Items for Systematic Reviews and Meta-Analyses quantitative fluorescence in situ hybridization

quantitative PCR 
medRxiv preprint doi: https://doi.org/10.1101/2020.11.23.20236992; this version posted November 24, 2020. The copyright holder for this preprint (which was not certified by peer review) is the author/funder, who has granted medRxiv a license to display the preprint in It is made available under a CC-BY-ND 4.0 International license .

592 RRMS relapsing-remitting multiple sclerosis

593 S single-copy gene signal

$594 \quad$ SMD standardized mean difference

$595 \quad$ SPMS secondary progressive multiple sclerosis

$596 \quad$ T telomere signal

597 TERC telomerase RNA component

$598 \quad$ TERT telomerase reverse trancriptase

$599 \quad$ TeSLA telomere shortest length assay

$600 \quad \mathrm{TL} \quad$ telomere length

601 TRF terminal restriction fragment

602 U-STELA universal single telomere length analysis

603 vs. versus 
medRxiv preprint doi: https://doi.org/10.1101/2020.11.23.20236992; this version posted November 24, 2020. The copyright holder for this preprint (which was not certified by peer review) is the author/funder, who has granted medRxiv a license to display the preprint in It is made available under a CC-BY-ND 4.0 International license.

\section{Authors' contributions}

605 JB performed the literature search, prepared all tables and drafted the manuscript. MH critically

606 revised the manuscript for importent intellectual content and conducted the meta-analysis. BF

607 contributed to the interpretation of published material and the writing of the manuscript. UKZ

608 conceptualized and supervised the research. All authors commented on previous versions of

609 the manuscript. All authors read and approved the final manuscript.

\section{Acknowledgments}

$611 \quad$ None to declare.

\section{Funding}

$613 \quad$ No funding was received for conducting the submitted work.

\section{Conflicts of interests}

615 The authors have no financial or non-financial interests to declare that are relevant to the 616 content of this article. 
medRxiv preprint doi: https://doi.org/10.1101/2020.11.23.20236992; this version posted November 24,2020 . The copyright holder for this preprint (which was not certified by peer review) is the author/funder, who has granted medRxiv a license to display the preprint in It is made available under a CC-BY-ND 4.0 International license .

\section{References}

[1] Goodin DS. The epidemiology of multiple sclerosis: insights to a causal cascade. Handb Clin Neurol. 2016;138:173-206. doi:10.1016/B978-0-12-802973-2.00011-2

[2] Walton C, King R, Rechtman L, et al. Rising prevalence of multiple sclerosis worldwide: Insights from the Atlas of MS, third edition. Mult Scler. 2020;1352458520970841. doi:10.1177/1352458520970841

[3] Filippi M, Bar-Or A, Piehl F, et al. Multiple sclerosis. Nat Rev Dis Primers. 2018;4(1):43. doi:10.1038/s41572-018-0041-4

[4] Kurtzke JF. Rating neurologic impairment in multiple sclerosis: an expanded disability status scale (EDSS). Neurology. 1983;33(11):1444-1452. doi:10.1212/wnl.33.11.1444

[5] Confavreux C, Vukusic S. The clinical course of multiple sclerosis. Handb Clin Neurol. 2014;122:343-369. doi:10.1016/B978-0-444-52001-2.00014-5

[6] Lublin FD, Reingold SC, Cohen JA, et al. Defining the clinical course of multiple sclerosis: the 2013 revisions. Neurology. 2014;83(3):278-286.

doi:10.1212/WNL.0000000000000560

[7] Koch-Henriksen N, Sørensen PS. The changing demographic pattern of multiple sclerosis epidemiology. Lancet Neurol. 2010;9(5):520-532. doi:10.1016/S1474-4422(10)70064-8

[8] Orton SM, Herrera BM, Yee IM, et al. Sex ratio of multiple sclerosis in Canada: a longitudinal study. Lancet Neurol. 2006;5(11):932-936. doi:10.1016/S1474-

4422(06)70581-6

[9] Golden LC, Voskuhl R. The importance of studying sex differences in disease: The example of multiple sclerosis. J Neurosci Res. 2017;95(1-2):633-643.

doi:10.1002/jnr.23955

[10] Belbasis L, Bellou V, Evangelou E, Ioannidis JP, Tzoulaki I. Environmental risk factors and multiple sclerosis: an umbrella review of systematic reviews and meta-analyses. Lancet Neurol. 2015;14(3):263-273. doi:10.1016/S1474-4422(14)70267-4

[11] Pakpoor J, Disanto G, Gerber JE, et al. The risk of developing multiple sclerosis in individuals seronegative for Epstein-Barr virus: a meta-analysis. Mult Scler. 2013;19(2):162-166. doi:10.1177/1352458512449682

[12] Engdahl E, Gustafsson R, Huang J, et al. Increased Serological Response Against Human Herpesvirus 6A Is Associated With Risk for Multiple Sclerosis. Front Immunol. 2019;10:2715. doi:10.3389/fimmu.2019.02715

[13] Alfredsson L, Olsson T. Lifestyle and Environmental Factors in Multiple Sclerosis. Cold Spring Harb Perspect Med. 2019;9(4):a028944. doi:10.1101/cshperspect.a028944

[14] Olsson T, Barcellos LF, Alfredsson L. Interactions between genetic, lifestyle and environmental risk factors for multiple sclerosis. Nat Rev Neurol. 2017;13(1):25-36. doi:10.1038/nrneurol.2016.187 
medRxiv preprint doi: https://doi.org/10.1101/2020.11.23.20236992; this version posted November 24,2020 . The copyright holder for this preprint (which was not certified by peer review) is the author/funder, who has granted medRxiv a license to display the preprint in It is made available under a CC-BY-ND 4.0 International license .

[15] Lincoln MR, Montpetit A, Cader MZ, et al. A predominant role for the HLA class II region in the association of the MHC region with multiple sclerosis. Nat Genet. 2005;37(10):11081112. doi:10.1038/ng1647

[16] Dobson R, Giovannoni G. Multiple sclerosis - a review. Eur J Neurol. 2019;26(1):27-40. doi:10.1111/ene.13819

[17] Moutsianas L, Jostins L, Beecham AH, et al. Class II HLA interactions modulate genetic risk for multiple sclerosis. Nat Genet. 2015;47(10):1107-1113. doi:10.1038/ng.3395

[18] International Multiple Sclerosis Genetics Consortium. Multiple sclerosis genomic map implicates peripheral immune cells and microglia in susceptibility. Science. 2019;365(6460):eaav7188. doi:10.1126/science.aav7188

[19] Baranzini SE, Oksenberg JR. The Genetics of Multiple Sclerosis: From 0 to 200 in 50 Years. Trends Genet. 2017;33(12):960-970. doi:10.1016/j.tig.2017.09.004

[20] Wang S, Madu CO, Lu Y. Telomere and Its Role in Diseases. Oncomedicine. 2019;4:1-9. doi:10.7150/oncm.28210

[21] Anitha A, Thanseem I, Vasu MM, Viswambharan V, Poovathinal SA. Telomeres in neurological disorders. Adv Clin Chem. 2019;90:81-132. doi:10.1016/bs.acc.2019.01.003

[22] Saretzki G. Telomeres, Telomerase and Ageing. Subcell Biochem. 2018;90:221-308. doi:10.1007/978-981-13-2835-0_9

[23] Moyzis RK, Buckingham JM, Cram LS, et al. A highly conserved repetitive DNA sequence, (TTAGGG)n, present at the telomeres of human chromosomes. Proc Natl Acad Sci U S A. 1988;85(18):6622-6626. doi:10.1073/pnas.85.18.6622

[24] de Lange T. Shelterin: the protein complex that shapes and safeguards human telomeres. Genes Dev. 2005;19(18):2100-2110. doi:10.1101/gad.1346005

[25] Corbett N, Alda M. On telomeres long and short. J Psychiatry Neurosci. 2015;40(1):3-4. doi:10.1503/jpn.140347

[26] Marioni RE, Harris SE, Shah S, et al. The epigenetic clock and telomere length are independently associated with chronological age and mortality. Int J Epidemiol. 2018;45(2):424-432. doi:10.1093/ije/dyw041

[27] Hayflick L, Moorhead PS. The serial cultivation of human diploid cell strains. Exp Cell Res. 1961;25:585-621. doi:10.1016/0014-4827(61)90192-6

[28] von Zglinicki T. Oxidative stress shortens telomeres. Trends Biochem Sci. 2002;27(7):339-344. doi:10.1016/s0968-0004(02)02110-2

[29] Gorenjak V, Akbar S, Stathopoulou MG, Visvikis-Siest S. The future of telomere length in personalized medicine. Front Biosci (Landmark Ed). 2018;23:1628-1654. doi:10.2741/4664

[30] Bellon M, Nicot C. Telomere Dynamics in Immune Senescence and Exhaustion Triggered by Chronic Viral Infection. Viruses. 2017;9(10):289. doi:10.3390/v9100289

[31] Dowd JB, Bosch JA, Steptoe A, et al. Persistent Herpesvirus Infections and Telomere 
medRxiv preprint doi: https://doi.org/10.1101/2020.11.23.20236992; this version posted November 24,2020 . The copyright holder for this preprint (which was not certified by peer review) is the author/funder, who has granted medRxiv a license to display the preprint in It is made available under a CC-BY-ND 4.0 International license.

Attrition Over 3 Years in the Whitehall II Cohort. J Infect Dis. 2017;216(5):565-572. doi:10.1093/infdis/jix255

[32] Du M, Prescott J, Kraft P, et al. Physical activity, sedentary behavior, and leukocyte telomere length in women. Am J Epidemiol. 2012;175(5):414-422. doi:10.1093/aje/kwr330

[33] Wright WE, Piatyszek MA, Rainey WE, Byrd W, Shay JW. Telomerase activity in human germline and embryonic tissues and cells. Dev Genet. 1996;18(2):173-179. doi:10.1002/(SICI)1520-6408(1996)18:2<173::AID-DVG10>3.0.CO;2-3

[34] Kim NW, Piatyszek MA, Prowse KR, et al. Specific association of human telomerase activity with immortal cells and cancer. Science. 1994;266(5193):2011-2015. doi:10.1126/ science. 7605428

[35] Shay JW, Bacchetti S. A survey of telomerase activity in human cancer. Eur J Cancer. 1997;33(5):787-791. doi:10.1016/S0959-8049(97)00062-2

[36] Mensà E, Latini S, Ramini D, Storci G, Bonafè M, Olivieri F. The telomere world and aging: Analytical challenges and future perspectives. Ageing Res Rev. 2019;50:27-42. doi:10.1016/j.arr.2019.01.004

[37] Cawthon RM. Telomere measurement by quantitative PCR. Nucleic Acids Res. 2002;30(10):e47. doi:10.1093/nar/30.10.e47

[38] Cawthon RM. Telomere length measurement by a novel monochrome multiplex quantitative PCR method. Nucleic Acids Res. 2009;37(3):e21. doi:10.1093/nar/gkn1027

[39] Lai TP, Zhang N, Noh J, et al. A method for measuring the distribution of the shortest telomeres in cells and tissues. Nat Commun. 2017;8(1):1356. doi:10.1038/s41467-01701291-z

[40] Lai TP, Wright WE, Shay JW. Comparison of telomere length measurement methods. Philos Trans R Soc Lond B Biol Sci. 2018;373(1741):20160451. doi:10.1098/rstb.2016.0451

[41] Demanelis K, Jasmine F, Chen LS, et al. Determinants of telomere length across human tissues. Science. 2020;369(6509):eaaz6876. doi:10.1126/science.aaz6876

[42] Aubert G, Baerlocher GM, Vulto I, Poon SS, Lansdorp PM. Collapse of telomere homeostasis in hematopoietic cells caused by heterozygous mutations in telomerase genes. PLoS Genet. 2012;8(5):e1002696. doi:10.1371/journal.pgen.1002696

[43] Barthel FP, Wei W, Tang M, et al. Systematic analysis of telomere length and somatic alterations in 31 cancer types. Nat Genet. 2017;49(3):349-357. doi:10.1038/ng.3781

[44] Liberati A, Altman DG, Tetzlaff J, et al. The PRISMA statement for reporting systematic reviews and meta-analyses of studies that evaluate health care interventions: explanation and elaboration. PLoS Med. 2009;6(7):e1000100. doi:10.1371/journal.pmed.1000100

[45] Poser CM, Paty DW, Scheinberg L, et al. New diagnostic criteria for multiple sclerosis: guidelines for research protocols. Ann Neurol. 1983;13(3):227-231.

doi:10.1002/ana.410130302

[46] McDonald WI, Compston A, Edan G, et al. Recommended diagnostic criteria for multiple 
medRxiv preprint doi: https://doi.org/10.1101/2020.11.23.20236992; this version posted November 24,2020 . The copyright holder for this preprint (which was not certified by peer review) is the author/funder, who has granted medRxiv a license to display the preprint in It is made available under a CC-BY-ND 4.0 International license.

sclerosis: guidelines from the International Panel on the diagnosis of multiple sclerosis. Ann Neurol. 2001;50(1):121-127. doi:10.1002/ana.1032

[47] Polman $\mathrm{CH}$, Reingold SC, Edan G, et al. Diagnostic criteria for multiple sclerosis: 2005 revisions to the "McDonald Criteria". Ann Neurol. 2005;58(6):840-846.

doi:10.1002/ana.20703

[48] Viechtbauer W. Conducting meta-analyses in R with the metafor package. J Stat Softw. 2010;36(3):1-48. doi:10.18637/jss.v036.i03

[49] Egger M, Davey Smith G, Schneider M, Minder C. Bias in meta-analysis detected by a simple, graphical test. BMJ. 1997;315(7109):629-634. doi:10.1136/bmj.315.7109.629

[50] Hug A, Korporal M, Schröder I, et al. Thymic export function and T cell homeostasis in patients with relapsing remitting multiple sclerosis. J Immunol. 2003;171(1):432-437. doi:10.4049/jimmunol.171.1.432

[51] Guan JZ, Guan WP, Maeda T, Guoqing X, GuangZhi W, Makino N. Patients with multiple sclerosis show increased oxidative stress markers and somatic telomere length shortening. Mol Cell Biochem. 2015;400(1-2):183-187. doi:10.1007/s11010-014-2274-1

[52] Guan JZ, Guan WP, Maeda T. Vitamin E administration erases an enhanced oxidation in multiple sclerosis. Can J Physiol Pharmacol. 2018;96(11):1181-1183. doi:10.1139/cjpp2018-0246

[53] Redondo J, Sarkar P, Kemp K, et al. Reduced cellularity of bone marrow in multiple sclerosis with decreased MSC expansion potential and premature ageing in vitro. Mult Scler. 2018;24(7):919-931. doi:10.1177/1352458517711276

[54] Krysko KM, Henry RG, Cree BAC, et al. Telomere Length Is Associated with Disability Progression in Multiple Sclerosis. Ann Neurol. 2019;86(5):671-682. doi:10.1002/ana.25592

[55] Habib R, Ocklenburg S, Hoffjan S, Haghikia A, Epplen JT, Arning L. Association between shorter leukocyte telomeres and multiple sclerosis. J Neuroimmunol. 2020;341:577187. doi:10.1016/j.jneuroim.2020.577187

[56] Hecker M, Fitzner B, Jaeger K, Buehring J, Schwartz M, Hartmann A, Walter M, Zettl UK. Leukocyte telomere length in patients with multiple sclerosis and its association with clinical phenotypes. medRxiv. 2020.11.17.20232975. doi:10.1101/2020.11.17.20232975

[57] Turner KJ, Vasu V, Griffin DK. Telomere Biology and Human Phenotype. Cells. 2019;8(1):73. doi:10.3390/cells8010073

[58] Thompson AJ, Banwell BL, Barkhof $F$, et al. Diagnosis of multiple sclerosis: 2017 revisions of the McDonald criteria. Lancet Neurol. 2018;17(2):162-173. doi:10.1016/S14744422(17)30470-2

[59] Lin J, Cheon J, Brown R, et al. Systematic and Cell Type-Specific Telomere Length Changes in Subsets of Lymphocytes. J Immunol Res. 2016;2016:5371050. doi:10.1155/2016/5371050

[60] Eitan E, Hutchison ER, Mattson MP. Telomere shortening in neurological disorders: an abundance of unanswered questions. Trends Neurosci. 2014;37(5):256-263. 
medRxiv preprint doi: https://doi.org/10.1101/2020.11.23.20236992; this version posted November 24,2020 . The copyright holder for this preprint (which was not certified by peer review) is the author/funder, who has granted medRxiv a license to display the preprint in It is made available under a CC-BY-ND 4.0 International license .

doi:10.1016/j.tins.2014.02.010

[61] Thomas P, O' Callaghan NJ, Fenech M. Telomere length in white blood cells, buccal cells and brain tissue and its variation with ageing and Alzheimer's disease. Mech Ageing Dev. 2008;129(4):183-190. doi:10.1016/j.mad.2007.12.004

[62] Slijepcevic P. Telomere length measurement by Q-FISH. Methods Cell Sci. 2001;23(13):17-22.

[63] Hemann MT, Strong MA, Hao LY, Greider CW. The shortest telomere, not average telomere length, is critical for cell viability and chromosome stability. Cell. 2001;107(1):6777. doi:10.1016/s0092-8674(01)00504-9

[64] Horvath S. DNA methylation age of human tissues and cell types. Genome Biol. 2013;14(10):R115. doi:10.1186/gb-2013-14-10-r115

[65] Horvath S, Gurven M, Levine ME, et al. An epigenetic clock analysis of race/ethnicity, sex, and coronary heart disease. Genome Biol. 2016;17(1):171. doi:10.1186/s13059-016-10300

[66] Levine ME, Lu AT, Quach A, et al. An epigenetic biomarker of aging for lifespan and healthspan. Aging (Albany NY). 2018;10(4):573-591. doi:10.18632/aging.101414

[67] Theodoropoulou E, Alfredsson L, Piehl F, Marabita F, Jagodic M. Different epigenetic clocks reflect distinct pathophysiological features of multiple sclerosis. Epigenomics. 2019;11(12):1429-1439. doi:10.2217/epi-2019-0102

[68] Bergsma T, Rogaeva E. DNA Methylation Clocks and Their Predictive Capacity for Aging Phenotypes and Healthspan. Neurosci Insights. 2020;15:2633105520942221. doi:10.1177/2633105520942221

[69] Belsky DW, Moffitt TE, Cohen AA, et al. Eleven Telomere, Epigenetic Clock, and Biomarker-Composite Quantifications of Biological Aging: Do They Measure the Same Thing?. Am J Epidemiol. 2018;187(6):1220-1230. doi:10.1093/aje/kwx346

[70] He S, Sharpless NE. Senescence in Health and Disease. Cell. 2017;169(6):1000-1011. doi:10.1016/j.cell.2017.05.015

[71] Kim W, Shay JW. Long-range telomere regulation of gene expression: Telomere looping and telomere position effect over long distances (TPE-OLD). Differentiation. 2018;99:1-9. doi:10.1016/j.diff.2017.11.005

[72] Xu Q, Parks CG, DeRoo LA, Cawthon RM, Sandler DP, Chen H. Multivitamin use and telomere length in women. Am J Clin Nutr. 2009;89(6):1857-1863.

doi:10.3945/ajcn.2008.26986

[73] Richards JB, Valdes AM, Gardner JP, et al. Higher serum vitamin D concentrations are associated with longer leukocyte telomere length in women. Am J Clin Nutr. 2007;86(5):1420-1425. doi:10.1093/ajcn/86.5.1420

[74] Yeh WZ, Gresle M, Jokubaitis V, Stankovich J, van der Walt A, Butzkueven H. Immunoregulatory effects and therapeutic potential of vitamin $\mathrm{D}$ in multiple sclerosis. $\mathrm{Br} \mathrm{J}$ Pharmacol. 2020;177(18):4113-4133. doi:10.1111/bph.15201 
medRxiv preprint doi: https://doi.org/10.1101/2020.11.23.20236992; this version posted November 24,2020 . The copyright holder for this

preprint (which was not certified by peer review) is the author/funder, who has granted medRxiv a license to display the preprint in

It is made available under a CC-BY-ND 4.0 International license.

[75] Waslo C, Bourdette D, Gray N, Wright K, Spain R. Lipoic Acid and Other Antioxidants as Therapies for Multiple Sclerosis. Curr Treat Options Neurol. 2019;21(6):26.

doi:10.1007/s11940-019-0566-1

[76] Prata LGPL, Ovsyannikova IG, Tchkonia T, Kirkland JL. Senescent cell clearance by the immune system: Emerging therapeutic opportunities. Semin Immunol. 2018;40:101275. doi:10.1016/j.smim.2019.04.003

[77] Robbins PD, Jurk D, Khosla S, et al. Senolytic Drugs: Reducing Senescent Cell Viability to Extend Health Span. Annu Rev Pharmacol Toxicol. 2021;61:31.1-31.25. doi:10.1146/annurev-pharmtox-050120-105018

[78] Baker DJ, Wijshake T, Tchkonia T, et al. Clearance of p16Ink4a-positive senescent cells delays ageing-associated disorders. Nature. 2011;479(7372):232-236.

doi:10.1038/nature10600

[79] Oost W, Talma N, Meilof JF, Laman JD. Targeting senescence to delay progression of multiple sclerosis. J Mol Med (Berl). 2018;96(11):1153-1166. doi:10.1007/s00109-0181686-x

[80] Jäger K, Walter M. Therapeutic Targeting of Telomerase. Genes (Basel). 2016;7(7):39. doi:10.3390/genes7070039

[81] Lünemann JD, Ruck T, Muraro PA, Bar-Or A, Wiendl H. Immune reconstitution therapies: concepts for durable remission in multiple sclerosis. Nat Rev Neurol. 2020;16(1):56-62. doi:10.1038/s41582-019-0268-z 
medRxiv preprint doi: https://doi.org/10.1101/2020.11.23.20236992; this version posted November 24, 2020. The copyright holder for this preprint (which was not certified by peer review) is the author/funder, who has granted medRxiv a license to display the preprint in perpetuity.

\section{Figures}

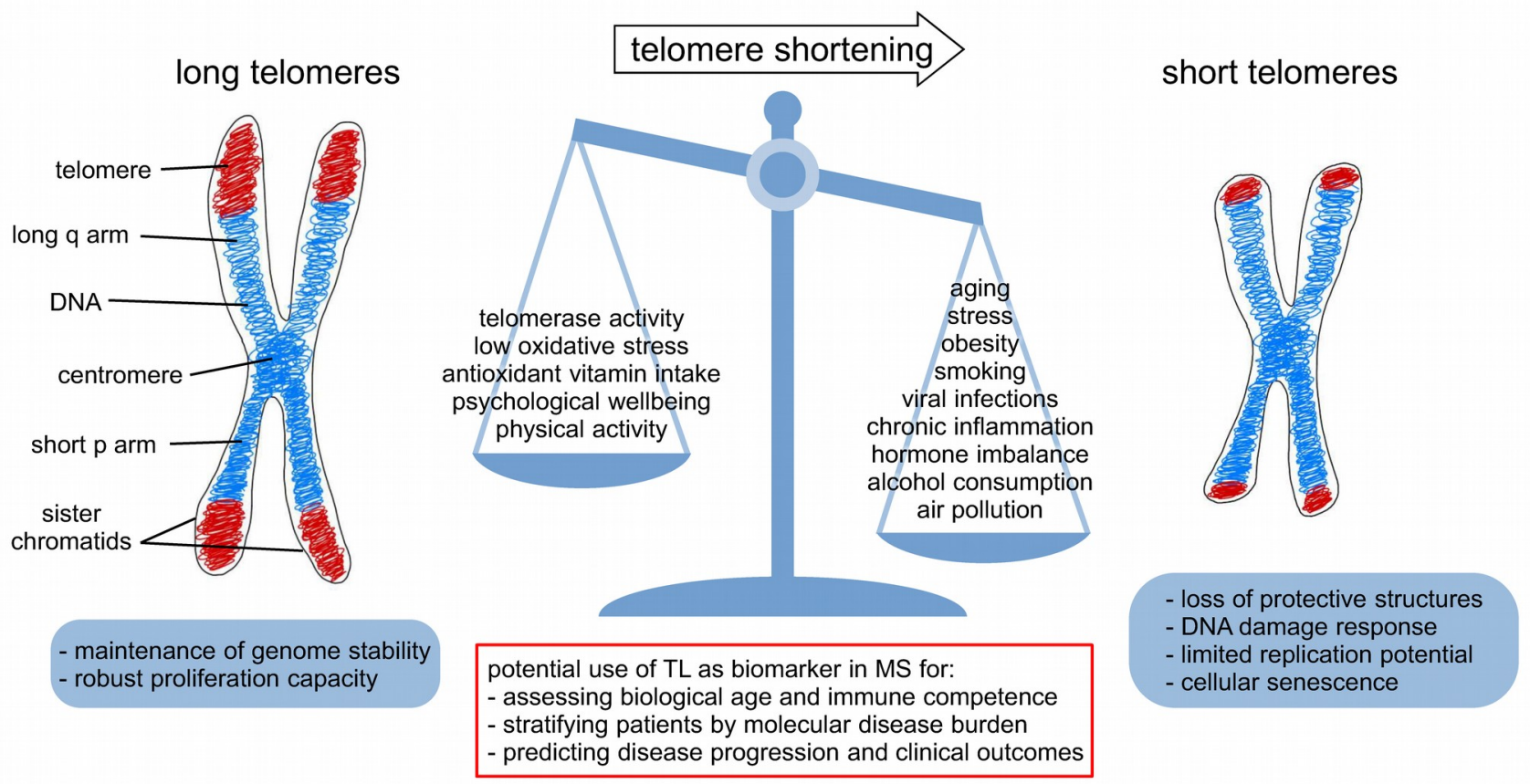

620 Figure 1: Factors contributing to accelerated telomere shortening.

621 A metaphase chromosome is depicted on the left. The telomeres are highlighted in red and not drawn to

622 scale in the diagram. They are located at the ends of the chromosome arms and consist of TTAGGG tandem

623 repeat sequences $(5-15 \mathrm{~kb}$ in humans). The centromere holds the two sister chromatids together. In normal

624 cells, telomeres shorten with every cell division. Apart from individual genetic determinants that affect

625 telomere length ( $\mathrm{TL}$ ), various environmental and lifestyle factors are known to influence telomere attrition.

626 Disruption of telomere maintenance is associated with end-to-end chromosome fusion. Critically short

627 telomeres trigger DNA damage responses such as cell cycle arrest. Telomere biology thus plays a crucial

628 role in health and disease. In multiple sclerosis (MS), the analysis of TL may serve as a biomarker of the

629 patients' immunosenescence status to assess and predict clinical disease phenotypes. 
medRxiv preprint doi: https://doi.org/10.1101/2020.11.23.20236992; this version posted November 24,2020 . The copyright holder for this preprint (which was not certified by peer review) is the author/funder, who has granted medRxiv a license to display the preprint in

It is made available under a CC-BY-ND 4.0 International license.

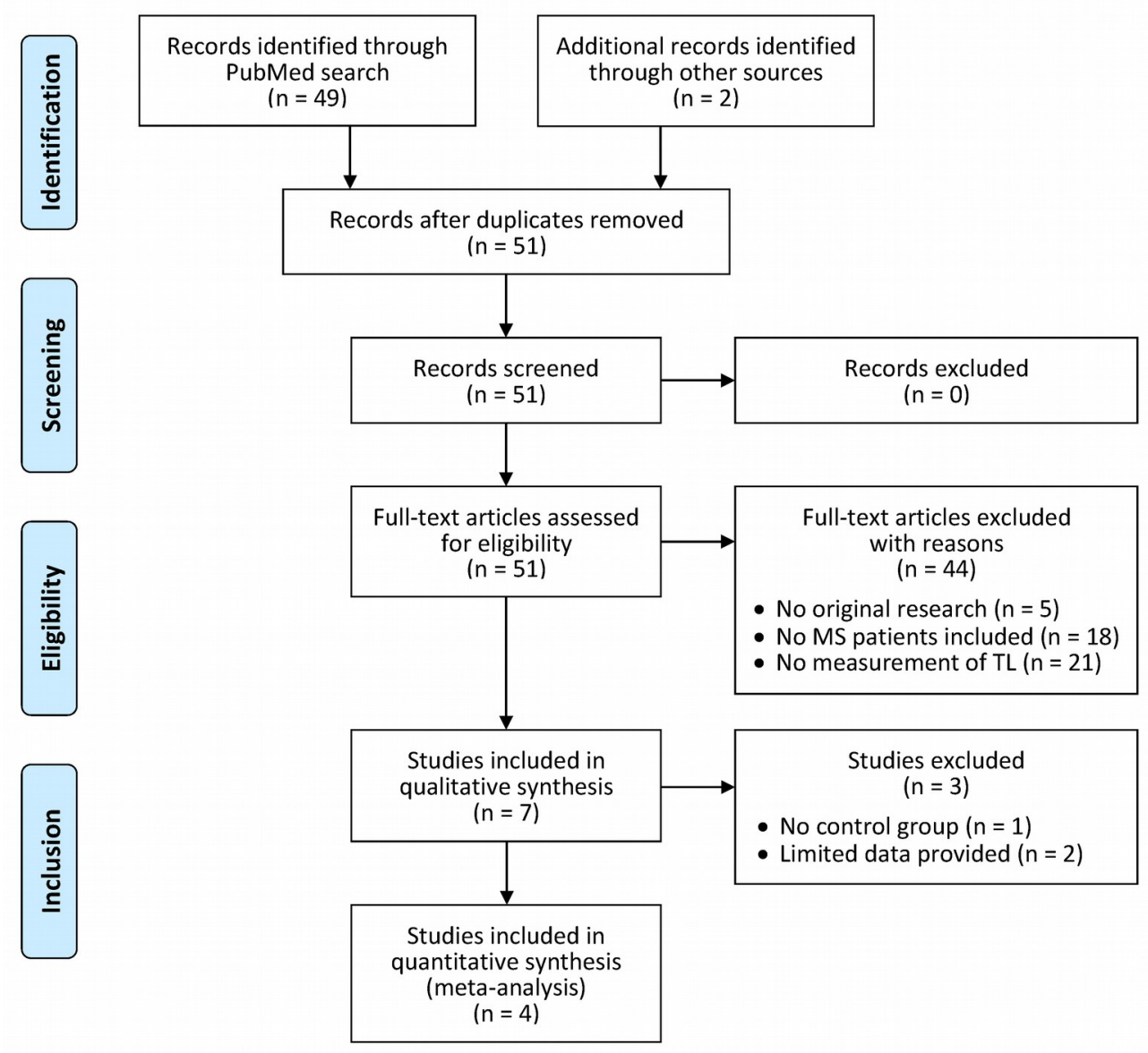

\section{Figure 2: PRISMA flow diagram of the study selection process.}

632 Following the Preferred Reporting Items for Systematic Reviews and Meta-Analyses (PRISMA statement) 633 [44], we considered the four steps identification, screening, eligibility and inclusion to identify studies for our 634 systematic review. The boxes that are connected through arrows show the steps of the selection process 635 and the number of articles that were included or excluded. A total of 51 articles were found in the literature 636 databases and evaluated for eligibility. The study selection finally revealed 7 studies on telomere lengths (TL) 637 in patients with multiple sclerosis (MS). A subset of 4 studies was included in the meta-analysis. 
medRxiv preprint doi: https://doi.org/10.1101/2020.11.23.20236992; this version posted November 24, 2020. The copyright holder for this preprint (which was not certified by peer review) is the author/funder, who has granted medRxiv a license to display the preprint in It is made available under a CC-BY-ND 4.0 International license.
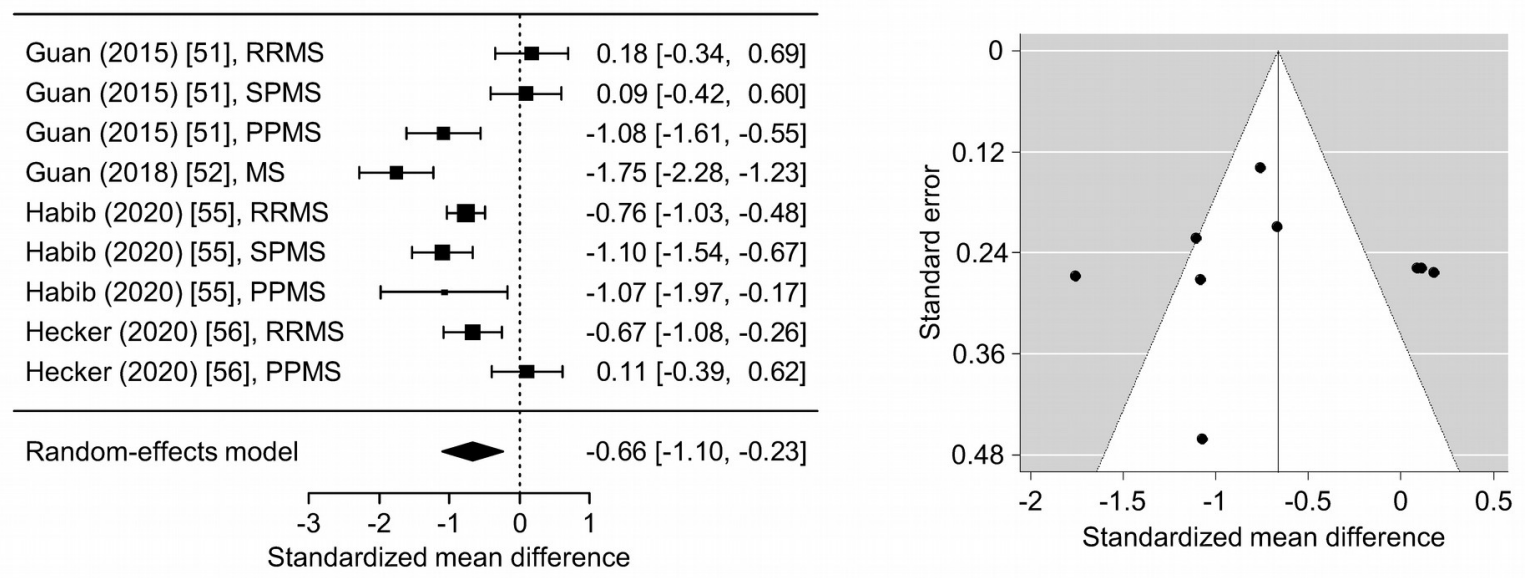

639 Figure 3: Meta-analysis of the relationship between telomere length and multiple sclerosis.

640 The meta-analysis was based on the results of 4 studies. The forest plot on the left shows the standardized

641 mean differences with 95\% confidence intervals for the comparisons of leukocyte telomere lengths (TL) in

642 patients with multiple sclerosis (MS) versus healthy controls in the individual studies and based on a random-

643 effects model. The summary estimate of -0.66 indicated significantly shorter TL in MS $(p=0.003)$, and the

644 Cochran's $Q$ test indicated heterogeneity across the studies $(p<0.001)$. The funnel plot on the right showed

645 no apparent asymmetry, and Egger's regression test detected no evidence of publication bias $(p=0.771)$.

646 PPMS = primary progressive MS; RRMS = relapsing-remitting MS; SPMS = secondary progressive MS 
medRxiv preprint doi: https://doi.org/10.1101/2020.11.23.20236992; this version posted November 24, 2020. The copyright holder for this preprint (which was not certified by peer review) is the author/funder, who has granted medRxiv a license to display the preprint in It is made available under a CC-BY-ND 4.0 International license.

\section{Tables}

648 Table 1: General information about the 7 studies that were included in this review.

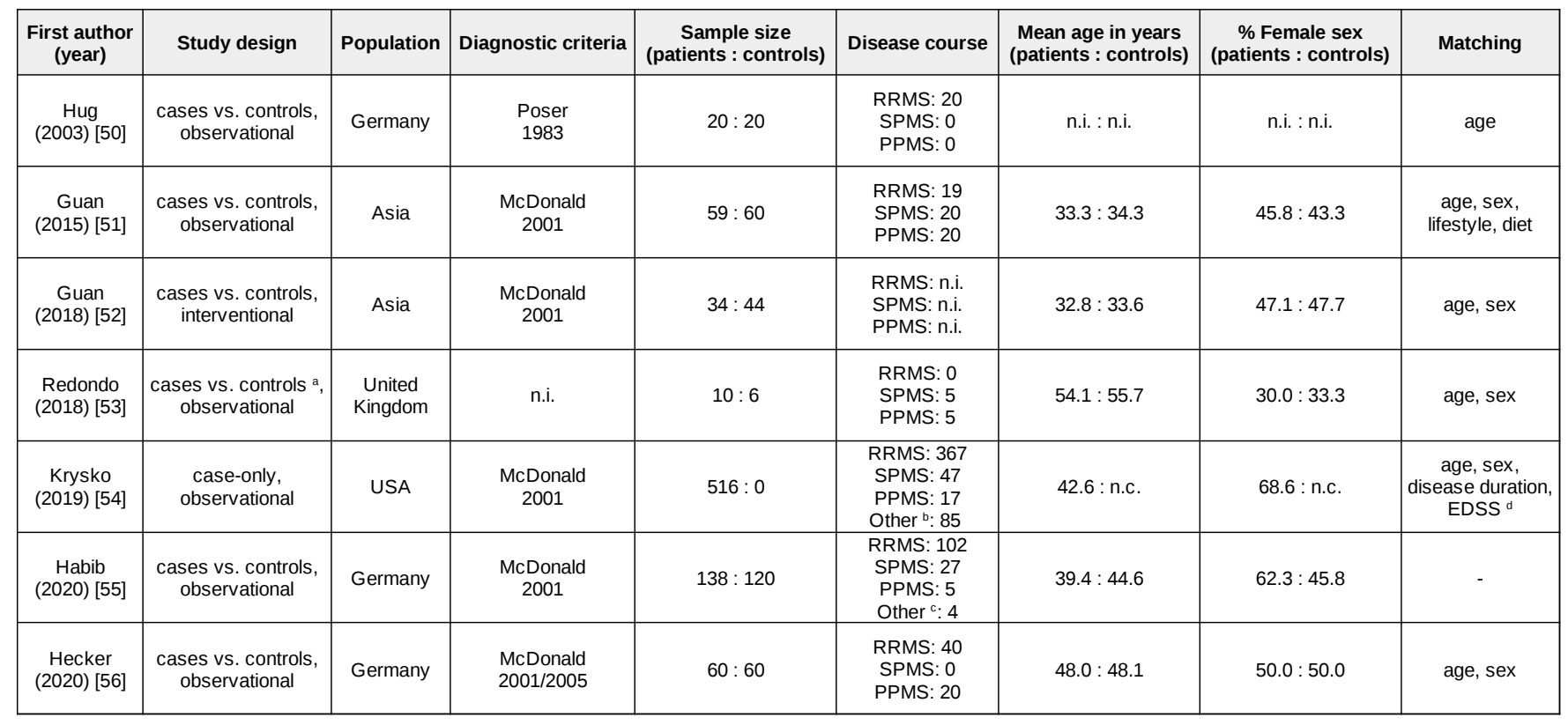

650 In total, we have identified 7 studies in which telomere lengths (TL) were measured in patients with multiple 651 sclerosis (MS). With one exception, all studies also included a control cohort. In the only interventional study, 652 the impact of vitamin E supplementation on TL was explored. The patients were diagnosed according to the 653 Poser criteria [45] or the (revised) McDonald criteria [46,47]. Furthermore, the study populations differed with 654 regard to sample size, MS subtype composition, age distribution and proportion of women. The study cohorts 655 were often matched for demographic characteristics to account for potential confounding in the TL analysis.

$656{ }^{a}=$ controls were not healthy (controls underwent total hip replacement for indication of osteoarthritis)

$657{ }^{b}=$ comprises 80 patients with clinically isolated syndrome, 4 patients with progressive relapsing MS and

6581 patient with an unclear diagnosis

$659^{c}=$ subtype of MS unclear

$66{ }^{d}=$ matching was assured for a subset of SPMS converters and non-converters $(n=46)$ with TL measured 661 longitudinally (no control cohort in this study)

662 EDSS = Expanded Disability Status Scale; n.c. = no control group; n.i. = no information; $P$ PMS = primary 663 progressive MS; RRMS = relapsing-remitting MS; SPMS = secondary progressive MS 
medRxiv preprint doi: https://doi.org/10.1101/2020.11.23.20236992; this version posted November 24,2020 . The copyright holder for this preprint (which was not certified by peer review) is the author/funder, who has granted medRxiv a license to display the preprint in

perpetuity.

664 Table 2: Methodological details and findings of the 7 studies on TL in MS patients.

\begin{tabular}{|c|c|c|c|c|c|c|c|c|}
\hline $\begin{array}{c}\text { First author } \\
\text { (year) }\end{array}$ & $\begin{array}{l}\text { Type of } \\
\text { specimen }\end{array}$ & $\begin{array}{l}\text { Sampling } \\
\text { strategy }\end{array}$ & $\begin{array}{c}\text { Method for } \\
\text { TL measurement }\end{array}$ & $\begin{array}{l}\text { Variables considered } \\
\text { as confounders }\end{array}$ & $\begin{array}{c}\text { TL in } \\
\text { MS patients }\end{array}$ & $\begin{array}{l}\text { TL in } \\
\text { controls }\end{array}$ & $\begin{array}{l}\text { Association of TL } \\
\text { with MS diagnosis }\end{array}$ & $\begin{array}{l}\text { Other associations } \\
\text { with TL }\end{array}$ \\
\hline $\begin{array}{c}\text { Hug } \\
\text { (2003) [50] }\end{array}$ & $\begin{array}{c}\text { peripheral blood } \\
\text { CD4+ and CD8+ } \\
\text { T cells }\end{array}$ & cross-sectional & TRF analysis & age & $\begin{array}{l}\text { CD4+: } 10.1 \mathrm{~kb} \\
\text { CD8+: } 9.2 \mathrm{~kb}\end{array}$ & $\begin{array}{l}\text { CD4+: } 8.8 \mathrm{~kb} \\
\text { CD8+: } 9.4 \mathrm{~kb}\end{array}$ & - & age $\downarrow$ \\
\hline $\begin{array}{c}\text { Guan } \\
\text { (2015) [51] }\end{array}$ & $\begin{array}{c}\text { peripheral } \\
\text { blood leukocytes }\end{array}$ & cross-sectional & TRF analysis & - & $\begin{array}{l}\text { RRMS: } 9.5 \pm 0.8 \mathrm{~kb} \\
\text { SPMS: } 9.3 \pm 0.9 \mathrm{~kb} \\
\text { PPMS: } 6.7 \pm 0.7 \mathrm{~kb}\end{array}$ & $9.1 \pm 2.5 \mathrm{~kb}$ & PPMS $\downarrow$ & age $\downarrow^{b}$ \\
\hline $\begin{array}{c}\text { Guan } \\
\text { (2018) [52] }\end{array}$ & $\begin{array}{c}\text { peripheral } \\
\text { blood leukocytes }\end{array}$ & $\begin{array}{l}\text { cross-sectional } \\
\text { and longitudinal, } \\
\text { 3-month follow-up }\end{array}$ & TRF analysis & - & $6.9 \pm 1.0 \mathrm{~kb}$ & $9.1 \pm 1.4 \mathrm{~kb}$ & MS $\downarrow$ & - \\
\hline $\begin{array}{l}\text { Redondo } \\
\text { (2018) [53] }\end{array}$ & $\begin{array}{l}\text { bone marrow } \\
\text { cells (MSCs) }\end{array}$ & cross-sectional & TRF analysis & $\begin{array}{c}\text { age, } \\
\text { passage number }{ }^{c}\end{array}$ & not specified & not specified & - & $\begin{array}{c}\text { age } \downarrow \text {, } \\
\text { passage number } \downarrow \text { c,d }\end{array}$ \\
\hline $\begin{array}{l}\text { Krysko } \\
\text { (2019) [54] }\end{array}$ & $\begin{array}{c}\text { peripheral } \\
\text { blood leukocytes }\end{array}$ & $\begin{array}{l}\text { cross-sectional } \\
\text { and longitudinal, } \\
\text { 10-year follow-up }\end{array}$ & singleplex qPCR & $\begin{array}{c}\text { age, sex, } \\
\text { disease duration }\end{array}$ & $\begin{array}{l}0.97 \pm 0.18 \\
(5.6 \mathrm{~kb})\end{array}$ & n.c. & n.c. & $\begin{array}{l}\text { age } \downarrow \text {, EDSS } \downarrow \text {, } \\
\text { disease duration } \downarrow \text {, } \\
\text { low brain volume } \downarrow \text {, } \\
\text { relapse rate } \downarrow \text { e }\end{array}$ \\
\hline $\begin{array}{l}\text { Habib } \\
\text { (2020) [55] }\end{array}$ & $\begin{array}{c}\text { peripheral } \\
\text { blood leukocytes }\end{array}$ & cross-sectional & multiplex qPCR & age, sex & $\begin{array}{l}\text { RRMS: } 0.76 \pm 0.22 \\
\text { SPMS: } 0.67 \pm 0.21 \\
\text { PPMS: } 0.67 \pm 0.27\end{array}$ & $0.94 \pm 0.25$ & $\begin{array}{l}\text { RRMS } \downarrow \\
\text { SPMS } \downarrow \\
\text { PPMS } \downarrow\end{array}$ & $\begin{array}{l}\text { age } \downarrow \text {, EDSS } \downarrow \text {, } \\
\text { passage number } \downarrow^{c}\end{array}$ \\
\hline $\begin{array}{l}\text { Hecker } \\
(2020)[56]\end{array}$ & $\begin{array}{c}\text { peripheral } \\
\text { blood leukocytes }\end{array}$ & $\begin{array}{l}\text { cross-sectional } \\
\text { and longitudinal, } \\
>10 \text {-year follow-up }\end{array}$ & multiplex qPCR & age, sex & $\begin{array}{l}\text { RRMS: } 0.92 \pm 0.19 \\
\text { PPMS: } 1.16 \pm 0.35\end{array}$ & $1.12 \pm 0.35$ & RRMS $\downarrow$ & $\begin{array}{c}\text { age } \downarrow \text {, } \\
\text { transition to } S P M S \downarrow e\end{array}$ \\
\hline
\end{tabular}

666 In all but one study, average TL were examined in blood cell populations. In 4 studies, the sampling was

667 carried out at a single time point, whereas in the other 3 studies, samples were collected in a longitudinal

668 manner at least for a subgroup of patients. TRF analysis by Southern blotting or qPCR assays $[37,38]$ were

669 employed for TL quantification. The mean TL ( \pm standard deviation, if available) is given for each study

670 group. The statistical analyses usually included adjustments for confounding factors that were suspected to

671 contribute to variation in the data. In 4 out of 6 studies that compared cases and controls, significantly shorter

672 telomeres were observed in at least one MS subgroup. Other associations that were reported in the studies

673 are presented in the rightmost column.

$674 \downarrow=$ variable or group was found to be associated with significantly shorter telomeres

$675^{a}=$ depending on the measurement method used, the TL group averages from the cross-sectional analyses

676 are given in $\mathrm{kb}(\mathrm{TRF})$ or in relative values (qPCR)

$677^{b}=$ significance was reached only for controls and male SPMS patients

$678^{c}=$ referring to in vitro experiments with patient-derived cells

$679{ }^{\mathrm{d}}=$ decrease of TL with increasing passage number reached statistical significance only for MSCs from

680 MS patients but not for control MSCs

$681^{\mathrm{e}}=$ based on an analysis restricted to the subgroup of RRMS patients

682 EDSS = Expanded Disability Status Scale; $\mathrm{kb}=$ kilobases; $\mathrm{MS}=$ multiple sclerosis; $\mathrm{MSC}$ = mesenchymal

683 stromal cells; n.c. = no control group; $\mathrm{PPMS}=$ primary progressive MS; $\mathrm{PPCR}=$ quantitative polymerase

684 chain reaction; RRMS = relapsing-remitting MS; SPMS = secondary progressive MS; TL = telomere length;

685 TRF $=$ telomere restriction fragment 
medRxiv preprint doi: https://doi.org/10.1101/2020.11.23.20236992; this version posted November 24,2020 . The copyright holder for this preprint (which was not certified by peer review) is the author/funder, who has granted medRxiv a license to display the preprint in

It is made available under a CC-BY-ND 4.0 International license .

686 Supplemental Table 1: Full list of studies assessed for inclusion in this systematic review.

\begin{tabular}{|c|c|c|c|c|c|c|c|c|}
\hline Number & First author & $\begin{array}{c}\text { Year of } \\
\text { publication }\end{array}$ & PubMed or preprint identifier & $\begin{array}{l}\text { English or } \\
\text { German? }\end{array}$ & $\begin{array}{l}\text { Original } \\
\text { article? }\end{array}$ & $\begin{array}{l}\text { Samples from } \\
\text { MS patients? }\end{array}$ & $\begin{array}{l}\text { Measurement } \\
\text { of TL? }\end{array}$ & $\begin{array}{l}\text { Inclusion } \\
\text { in review }\end{array}$ \\
\hline 1 & Olerup & 1990 & 1978948 & yes & yes & yes & no & - \\
\hline 2 & Charmley & 1991 & 1674514 & yes & yes & yes & no & - \\
\hline 3 & Spurkland & 1994 & 8071104 & yes & yes & yes & no & - \\
\hline 4 & Roth & 1995 & 7499175 & yes & yes & no & no & - \\
\hline 5 & Torelli & 1995 & 7561787 & yes & yes & yes & no & - \\
\hline 6 & Pham-Dinh & 1995 & 7590972 & yes & yes & no & no & - \\
\hline 7 & Roth & 1995 & 7593547 & yes & yes & yes & no & - \\
\hline 8 & Encinas & 1996 & 8757345 & yes & yes & no & no & - \\
\hline 9 & De Boer & 1998 & 9637494 & yes & yes & no & no & - \\
\hline 10 & Morris & 1999 & 10223549 & yes & yes & no & no & - \\
\hline 11 & Bihl & 1999 & 10224268 & yes & yes & no & no & - \\
\hline 12 & Allcock & 1999 & 10369924 & yes & yes & no & no & - \\
\hline 13 & Stefferl & 1999 & 10384097 & yes & yes & no & no & - \\
\hline 14 & Kalman & 1999 & 10554670 & yes & no & no & no & - \\
\hline 15 & Allcock & 1999 & 10626741 & yes & yes & yes & no & - \\
\hline 16 & Oksenberg & 2000 & 11164900 & yes & no & no & no & - \\
\hline 17 & Encinas & 2001 & 11222494 & yes & yes & no & no & - \\
\hline 18 & Jawaheer & 2001 & 11254450 & yes & yes & no & no & - \\
\hline 19 & Marrosu & 2001 & 11741834 & yes & yes & yes & no & - \\
\hline 20 & Storch & 2002 & 12146797 & yes & yes & no & no & - \\
\hline 21 & Mellai & 2003 & 12559630 & yes & yes & yes & no & - \\
\hline 22 & Hug & 2003 & 12817027 & yes & yes & yes & yes & $\checkmark$ \\
\hline 23 & Duvefelt & 2003 & 14651518 & yes & yes & yes & no & - \\
\hline 24 & Rubio & 2004 & 15014978 & yes & yes & yes & no & - \\
\hline 25 & Jagodic & 2005 & 15634914 & yes & yes & no & no & - \\
\hline 26 & Muhallab & 2005 & 15748954 & yes & yes & no & no & - \\
\hline 27 & Vyskhina & 2005 & 16078049 & yes & yes & yes & no & - \\
\hline 28 & Weksler & 2005 & 16141364 & yes & yes & no & no & - \\
\hline 29 & Thewissen & 2005 & 16154497 & yes & yes & yes & no & - \\
\hline 30 & Marrosu & 2006 & 16096810 & yes & yes & yes & no & - \\
\hline 31 & Saarela & 2006 & 16596167 & yes & yes & yes & no & - \\
\hline 32 & Lamoury & 2006 & 16793732 & yes & yes & no & no & - \\
\hline 33 & Rubio & 2007 & 17256150 & yes & yes & yes & no & - \\
\hline 34 & Cailier & 2008 & 18832704 & yes & yes & yes & no & - \\
\hline 35 & Ordóñez & 2009 & 19421224 & yes & yes & yes & no & - \\
\hline 36 & Baecher-Allan & 2011 & 21300823 & yes & yes & yes & no & - \\
\hline 37 & Montoya & 2012 & 22770640 & yes & yes & no & no & - \\
\hline 38 & Oksenberg & 2013 & 24289837 & yes & no & no & no & - \\
\hline 39 & Westerlind & 2015 & 25159868 & yes & yes & yes & no & - \\
\hline 40 & Guan & 2015 & 25424527 & yes & yes & yes & yes & $\checkmark$ \\
\hline 41 & Reddy & 2017 & 28253983 & yes & no & no & no & - \\
\hline 42 & Cebrián-Silla & 2017 & 28648897 & yes & yes & no & no & - \\
\hline 43 & Redondo & 2018 & 28548004 & yes & yes & yes & yes & $\checkmark$ \\
\hline 44 & Guan & 2018 & 30092167 & yes & yes & yes & yes & $\checkmark$ \\
\hline 45 & Liu & 2019 & 31294790 & yes & yes & yes & no & - \\
\hline 46 & Din & 2019 & 31407831 & yes & yes & yes & no & - \\
\hline 47 & Krysko & 2019 & 31486104 & yes & yes & yes & yes & $\checkmark$ \\
\hline 48 & Habib & 2020 & 32050150 & yes & yes & yes & yes & $\checkmark$ \\
\hline 49 & Carraro & 2020 & 32499887 & yes & no & no & no & - \\
\hline 50 & Liu & 2020 & bioRxiv 2019.12.19.882522 & yes & yes & no & no & - \\
\hline 51 & Hecker & 2020 & medRxiv 2020.11.17.20232975 & yes & yes & yes & yes & $\checkmark$ \\
\hline
\end{tabular}

688 The literature search was conducted using the databases PubMed, bioRxiv and medRxiv with the search

689 terms "multiple sclerosis" and "telomer*". This resulted in 51 articles that were screened and assessed for

690 eligibility (sorted by year of publication). Based on previously defined study selection criteria, we excluded 44

691 of these articles. The included studies (marked by $\checkmark$ ) were original research articles written in English or

692 German that presented data on telomere lengths $(T L)$ measured in samples from patients with multiple

693 sclerosis (MS). 